Cotta, 1983. The third volume is G.W.F. Hegel, Vorlesung Uber Rechtsphilosophie, herausgegeben von $D$. Henrich, Frankfurt, Suhrkamp, 1983; it is the anonymous lecture notes of $1819 / 20$.

2. See Karl-Heinz Ilting, Hegel's Vorlesungen Uber Rechtsphilosophie 1818-1831, Stuttgart-Bad Cannstatt, Bd. 1; 1973, Bd.2; 1974, Bd.3; 1974, Bd.4; 1974. FrommannHolzboog.

3. For an obituary for liting and a bibliography of his works, see Hansgeorg Hoppe, 'Karl-Heinz Ilting (1925-1984)', Bulletin of the Hegel Society of Great Britain, no. 10, Autumn/Winter 1984.

\title{
1986 HSGB Conference: Preliminary Notice
}

The Eighth Annual Conference of the Hegel Society of Great Britain will be a twoday Joint Conference of the HSGB and the Hegel-Archiv der Ruhr-Universitat, Bochum. It will take place at Pembroke College, Oxford, on 11-13 September 1986 and have as its general theme, 'Politics-Philosophy-History'. Hegel's Philosophy of Right ends with a section on world history, and his lectures on the philosophy of history contain much that is relevant to his political philosophy. The main task of the conference will be to explore the connection between the two parts of Hegel's philosophical thought and its contemporary setting.

There will be ten papers (five by participants from each country), which will be formally commented on. Papers, and as far as possible comments, will be circulated in advance to those who have registered for the conference. The selection of papers and comnents and the general organisation of the Joint Conference is in the hands of a committee consisting of Prof. Otto PUggeler and Dr. Hans-Christian Lucas from Bochum and Prof. W.H. Walsh and Dr. 2.A. Pelczynski from Dxford. It is hoped to finalise the programme at the latest by Easter 1986.

Letters concerning the academic side of the Joint Conference should be addressed to Dr. Pelczynski at Pembroke College, Oxford OXI 1DW. The programme and registration forms can be obtained from Or. David Lamb, Dept. of Philosophy, The University, Manchester M13 9PL, to whom also cheques with registration fees should be sent. The registration fee will be $£ 2.50$ ( $£ 1.00$ for graduate student members of the HSGB), and there will also be a charge to help cover the cost of the xeroxing and postage of papers. Only fully paid-up members of the HSGB will be able to attend the Joint Conference on the British side. The cost of staying in Pembroke (a single room for two nights and six meals) will be $£ 50.00$.

\author{
Review Article
}

\section{Hegel's Jena Writings: Recent Trends in Research}

Hegel's Jena Writings (1801-7) are today practically within the reach of all: thanks to the thorough and scrupulous work done at the Hegel-Archiv of the RuhrUniversityt in Bochum, we now have at our disposal a completely revised edition of almost all these writings. 1 Many of them have also recently been translated into English. 2 